\begin{tabular}{|l|l|l|}
\hline \multicolumn{2}{|c|}{ PublisherInfo } \\
\hline \hline PublisherName & $:$ & BioMed Central \\
\hline \hline PublisherLocation & $:$ & London \\
\hline \hline PublisherImprintName & $:$ & BioMed Central \\
\hline \hline
\end{tabular}

\title{
A role for osteopontin in joint destruction
}

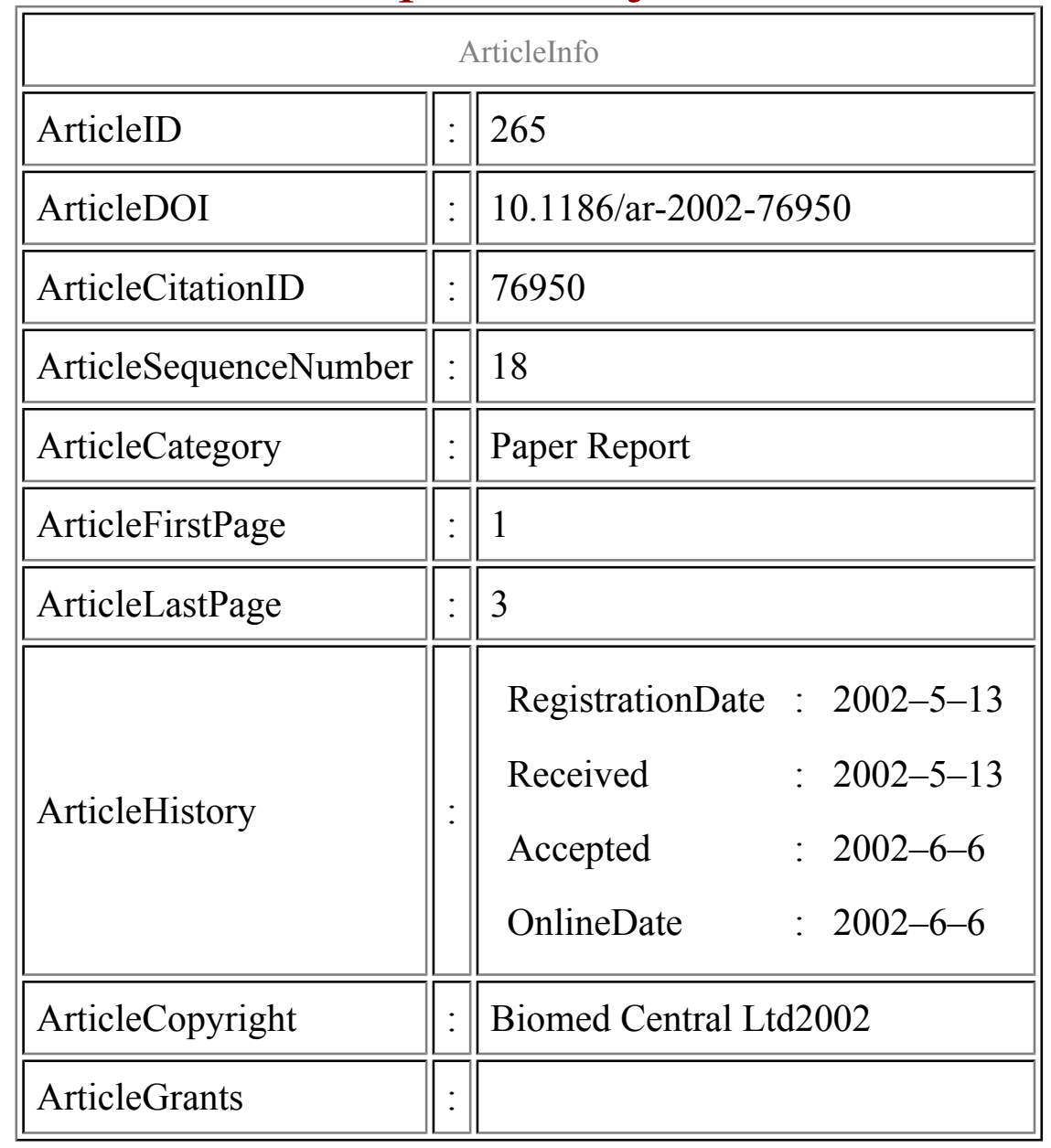




\begin{tabular}{|l|l|l||}
\hline ArticleContext & $:$ & 130754411 \\
\hline
\end{tabular}

Cheryl Smythe, ${ }^{\text {Affl }}$

Aff1 Imperial College, London, UK

\section{Keywords}

Cartilage, chondrocyte, osteopontin

\section{Context}

Osteopontin (OPN) is an extracellular matrix protein that may play a role in inflammatory arthritis. OPN expression has been observed in the proliferating synovial cells and at the interface of cartilage and invading synovium of rheumatoid patients. In order to understand the contribution OPN makes to the pathology of rheumatoid arthritis (RA), the authors have investigated progression of anti-type II collagen antibody-induced arthritis in wild-type and OPN-deficient animals.

\section{Significant findings}

Immunohistological analysis demonstrated that OPN expression was enhanced in the superficial and deep layers of cartilage in arthritic mice. Cartilage destruction, chondrocyte apoptosis, proteoglycan depletion, joint swelling and infiltration of inflammatory cells into the knee joint were all significantly reduced in OPN-deficient arthritic mice compared to wild-type arthritic controls. By measuring the level of PECAM-1-positive cells in the synovia as an indicator of angiogenesis, an increased level of angiogenesis was observed in arthritis-induced wild-type mice which was not seen in OPN-deficient arthritic animals. Serum TNF levels following LPS treatment were identical in OPN-deficient and wildtype mice. Levels of urinary D-Pyr, a marker of bone resorption, were elevated in arthritic wild-type mice, but remained at basal levels in OPN-deficient arthritic animals.

\section{Comments}


This study demonstrates that OPN plays an important role in the destruction of joint cartilage in RA, therefore identifying it as a potential therapeutic target. The Authors suggest that during arthritis OPN may be acting at multiple points: promoting chondrocyte apoptosis, bone loss, angiogenesis and T-cell activation. The effect of OPN deficiency over a longer time period in both healthy and arthritic mice remains to be determined. In addition, given that matrix metalloproteinases (MMPs) play a pivotal role in the depletion of proteoglycan and collagen leading to cartilage destruction, the effect of OPN deficiency on MMP expression would be interesting to explore. Finally, inhibitors of OPN formation or function now need to be tested for their efficacy in animal models of arthritis.

\section{Methods}

Anti-collagen antibody-induced arthritis, immunohistochemistry, TUNEL assay, scanning electron microscopy, ELISA

\section{References}

1. Yumoto K, Ishijima M, Rittling SR, Tsuji K, Tsuchiya Y, Kon S, Nifuji A, Uede T, Denhardt DT, Noda M: Osteopontin deficiency protects joints against destruction in anti-type II collagen antibody induced arthritis in mice. Proc Natl Acad Sci. 2002, 99: 4556-4561.

This PDF file was created after publication. 